\title{
Preventing students from dropping out of school in Indonesia's Basic Education: What should government do?
}

\author{
Reni Tri Pujiastuti ${ }^{1}$, Sujarwoto, Firda Hidayati \\ Department of Public Administration \\ University of Brawijaya \\ Malang, Indonesia \\ ${ }^{1}$ rheni.trip@gmail.com
}

\begin{abstract}
High students drop-out have been a critical issue of decentralized basic education in Indonesia. With around 2.6 million students (age 7-15 years old) who drop out of school, Indonesian government should promote effective policies for reducing school dropouts. We conducted a case study at Sleman regency to understand why decentralization policies failed to reduce school dropouts and what main reason of children dropped out of school in Indonesia's basic education. The findings suggest that dropping out of school could be a process of disadvantages caused by household socioeconomic deprivation and social marginalization, as well as disabling public policy. Instead of reducing school dropouts, we found that decentralized policy in term of fiscal autonomy may lead to the risk of school dropouts at the elementary school, transition, and junior high school levels. We found lack of efficiency on educational budget allocation and inefficiency in program implementations to be the main challenges that prevent district government from effectively reducing school dropouts. The findings suggest that local governments must improve their efficiency in allocating educational expenditures through implementing strategic policies that directly purposed to prevent students from dropping out of school.
\end{abstract}

Keywords-school dropout, socioeconomic factors, fiscal autonomy, qualitative, Indonesia

\section{INTRODUCTION}

Indonesian basic education system has been decentralized since 2001. Decentralization gives local governments more autonomy in managing several sectors including basic education. Local governments have been assigned to manage local revenues and district expenditures, to make policies and programs with some certain regulations. They also have been given responsibility to manage elementary schools and junior high schools in their jurisdictions such as funding schools, hiring teachers, and implementing programs, while central government has still responsible for national policy formulation, curriculum and overall quality assurance. This education decentralization should enable local governments to improve access, quality, and equity of education services, if they are well understand the underlying factors of decentralization and make the best use of.
The Indonesia's government has also recognized the urgency to support public investments in education. This commitment is guaranteed in the amended Constitution by obligating the national, provincial, and district government levels to allocate at least $20 \%$ of their annual spending to education. This constitution is enacted into Law No 20/2003 on the National Education System. According to Ministry of Finance (2016) education spending in Indonesia increased into $65.3 \%$ in 2015 account for IDR 408.5 trillion (USD 30.7 billion) compared to in 2011 for about IDR 266.9 trillion (USD 20.1 billion). Total education spending in sub-national level had also risen from 59.6 percent in 2011 into 62.2 percent in 2015, account for IDR 159 trillion (USD 11.6 billion) and IDR 254.2 trillion (USD 12 billion) respectively. The total education expenditure, in 2015 itself, achieved up to 20.6 percent on national aggregate (MoF, 2016).

Moreover, the government has also implemented several programs to ensure more children to enroll school and fewer children to drop out of school. First, school operational grants program has been put into practice since 2005 to reduce household financial burden so that parents are more willing to send their children to the school. Second, teacher certification program has been employed since 2006 to improve teacher competency and quality, as teachers are necessary for carrying learning process out and nurturing the students. Third, scholarship program and conditional cash transfer program have been realized since 2007 to prevent children from poor household for dropping out of school. The government has also abolished school tuition in public schools since 2012 as the central and district governments have increased the amount of school operational grants per each student.

Efforts by the government have achieved the success of enrollment rates in Indonesia; however, it has not shown effectively in preventing children from dropping out of school. Indonesia had not been effective in keeping all those children to finish until graduation. There were around $7.18 \%$ or 2.69 millions of elementary and junior high school students who dropped out of school before getting a junior high school certificate in 2014 (MoEC, 2015). In Sleman, even though the local government had targeted zero dropout number at elementary school level and junior high school level, but there were around 146 children aged between 7 
and 15 years old or $0.10 \%$ of the population who dropped out of school between 2013 and 2015 (Sleman's five-years report, 2016).

Thus, this research raises two main questions. First, why do children still drop out of school even with government efforts in bringing service provider to district government? Second, what effective policies that government should do to prevent children from dropping out of school in Indonesia's basic education?

\section{METHOD}

This study used a qualitative case study in one of local governments in Indonesia, namely Sleman District. Diversity of rural and urban areas in Sleman makes it an interesting case study since it has the highest income inequality among other districts in Yogyakarta Province, according to National Statistics Agency of Sleman (2016). The interview guide for children and parents was established on social behavior and motivation aspects. The interview guide for officers was established on educational budget allocation and program implementations. We collected the data through interviews, focus group discussion, and official documents between June 2016 and February 2017. We interviewed 42 school dropouts aged between 9 to 17 years old, who dropped out whether from elementary school, or transition level, or junior high school, and their parents. Open interview was used to ask reasons for dropping out of school with children and/or their parents, started with what occasion before they dropped were. Semistructured interview was used to identify household socioeconomic factors and schooling experiences, such as: 1) What are your parents' educational background and occupation? 2) How many persons living in the house, who are they, and what do they do? 3) What are government's financial assistance that you or your parents get? 4) What do you think about your schooling experiences? We also conducted open interviews with five local officials to understand challenges faced by districts government to implement programs during autonomy regulation. In addition, we held focus group discussion with 10 teachers and 10 principals to support the statements from children and local officials. In order to provide supporting evidences for the findings, we examined data from Sleman's official documents such as Sleman's five-year report (2016), education office and districts's annual budget documents (2012-2016).

\section{RESULT}

\section{A. Reasons and Factors for Dropping Out of School}

Based on interviews with school dropouts and parents, there were five reasons influencing children to drop out of school even with government efforts in bringing provider closer to the people and spreading free compulsory basic education. The reasons were household economic-related issue, bad peer-group influence, poor social relationship issue, low academic achievement, and health-related issue. Decision for dropping out of school could be seen as a process triggered by one or more of the reasons, while household socioeconomic issues and social marginalization were the factors influencing the process. Children dropped out of school because they faced not just one but several disadvantages from those mentioned issues. Figure 1 summarizes the reasons for dropping out experienced by the surveyed school dropouts.

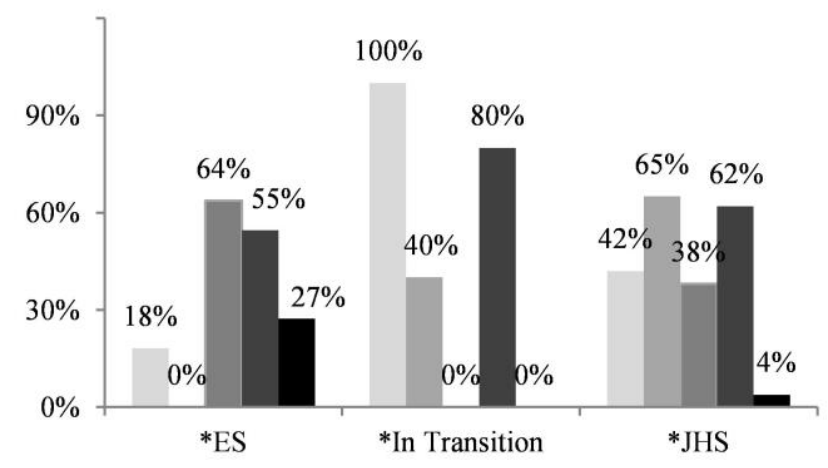

\footnotetext{
Economic-related issue

Bad peer-group influence

m Bad relationship with the teacher/schoolmate

- Low academic achievement

- Health-related issue
}

\section{Dropping out time}

*ES: during Elementary School; *In Transition: Graduated from Elementary School but not continue to Junior High School;

*JHS: during Junior High School

Source: Interview data

Figure 1. Reasons for dropping out of school mentioned by the surveyed children

Above figure suggests that at elementary school level, bad relationship with the teacher/schoolmate and low academic achievement dominate the dropped-out decisions for about $64 \%$ and $55 \%$ respectively. It seems that younger children are more likely to drop out of school if they have a bad relationship with the teacher or schoolmates and/or a poor academic performance. Meanwhile, economic-related issue and low academic achievement are more common at transition level comprised for $100 \%$ and $80 \%$ subsequently. It appears that household economic condition and/or unsatisfied academic evaluation result are more likely to become consideration for low income parents for sending their children to junior high school. Finally, bad peer-group influence and low academic achievement stand out as the first and the second highest reasons at junior high school level for around $65 \%$ and $62 \%$ correspondingly. It signals that older children are more likely to drop out because of their bad behavior influenced by their schoolmates or neighborhood friends, and/or their poor academic performance caused by their low motivation to study.

Our findings suggest that children with poor academic achievement, whose the rank becomes the second highest at all levels, are more likely to drop out of school if they are being neglected and unsupported, or feeling ashamed or frustrated. Based on interview, 26 out of 42 children mentioned about giving up going to school related with this 
issue. Younger children (elementary school students) mostly dropped out since they were being unsupported and neglected by their teachers because of their poor academic performance, and often got scolded then it made them traumatized. Having low academic evaluation result was also one of reasons for elementary school graduates for not continuing to the next school level because of uselessness and/or uncertainty toward their schooling future. Older children (junior high school students), meanwhile, dropped out as they had a dislike toward the teachers, which resulted to have low motivation to study and a low grade, then decided to drop out of school. It also led some of them to repeat grade for twice or more, and made them ashamed for being older than their classmates, then given up to go to school.

The next issue is bad relationship with the teacher/schoolmate, which becomes the most common reason for giving up school completion particularly at elementary school level. Indicating children who have bad experiences with teachers and/or schoolmates are more likely to drop out if they perceive exclusion and marginalization. Based on interview, 19 out of 42 children mentioned about their bad experiences with the teachers or schoolmates as one of reasons for dropping out of school. These children were having insecure feeling towards teachers or schoolmates who said mean words and behaved badly to them. They felt excluded and marginalized, then, they felt afraid, disappointed, or hatred. They, finally, did not want to see those teachers or schoolmates anymore. This bad schooling experience became a barrier to stay at school, or to find another school, or to adjust to the new school that made them finally dropped out from the new school.

Household economic deprivation is more likely to cause children, who live in low or middle-income family in particular, for leaving school because of feeling ashamed, envy, or useless. Based on interview, 17 out of 42 main respondents mentioned economic-related issue as one of reasons for dropping out of school especially at transition level. Some children wanted to get quick cash for being unskilled labor as mentioned by $56 \%$ of the 17 children. Other $39 \%$ of them mentioned that their parents could not afford to give daily pocket money for transport and snacks. Even if parents could actually afford but some of parents stated that they did not want to waste the money for their children's schooling since it would be useless. It was whether their children had low motivation to study or bad behavior. Some of children and parents also denied school benefits for the children's future as it would not help them to have skills for future earnings. Feeling ashamed or envy for being around with classmates who had more fancy things and disappointment to household economic deprivation were also mentioned as economic-related reasons for dropping out of school.

Finally, bad peer-group influence, which is considered as the highest reason for dropping out of school at junior high school level, is more likely to influence children, who have frustration, low self-esteem, and low self-determination, to drop out of school. Based on interview, 20 out of 42 respondents mentioned these kinds of signals. These children were having frustrations caused by the divorce of parents, the death of parent mainly the father, the lack of harmony in the family, the lack of parenting, or the unpleasant treatment by teachers. They met other schoolmates or neighborhood friends who had similar problems and started to talk to, and did some deviant behavior such as truancy, school gang activities, or others. These children also had friends who dropped out at the same time or already dropped out before them. It finally led them to the decision to stop schooling. It seemed that these children had less support, advice, control, and role model from the parents, teachers, and surrounding neighborhood.

\section{B. District Government's performances and its challenges}

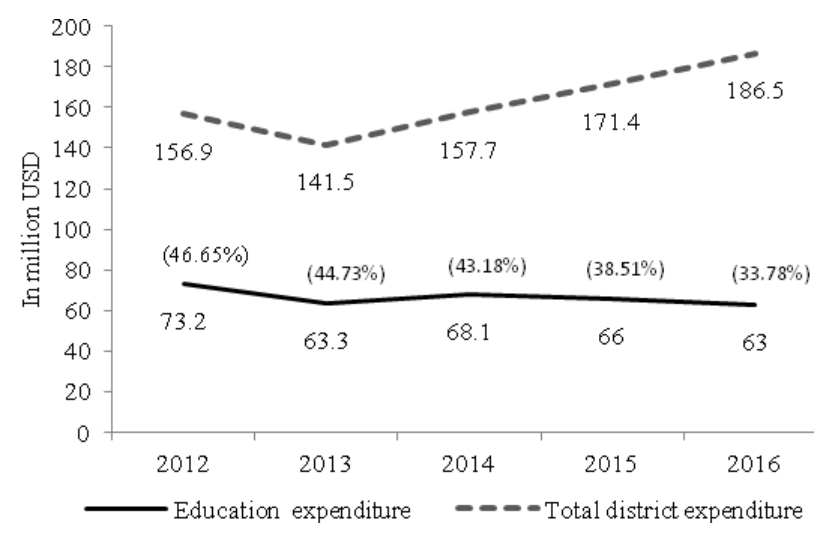

Source: calculation from district annual budget documents (2012-2016) and five-years report (2016) Source: calculation from district annual budget documents (2012-2016) and five-years report (2016)

Figure 2. Proportions of education expenditure to total district expenditure

We found that decentralized policy in term of fiscal autonomy has not been effective in improving allocative efficiency for program implementations in education sector. First, we found inefficiency in educational budget components indicated by imbalance proportion between personnel spending for civil servants and public teachers' salaries, and direct spending for program implementations. Even though the proportions of education spending in 20122016 exceeded more than $20 \%$ as mandated by the amended Constitution (Figure 2), the majority of district education spending in 2012-2016 went toward salaries and teacher allowances for about $89.3 \%$ in average (Figure 3 ).

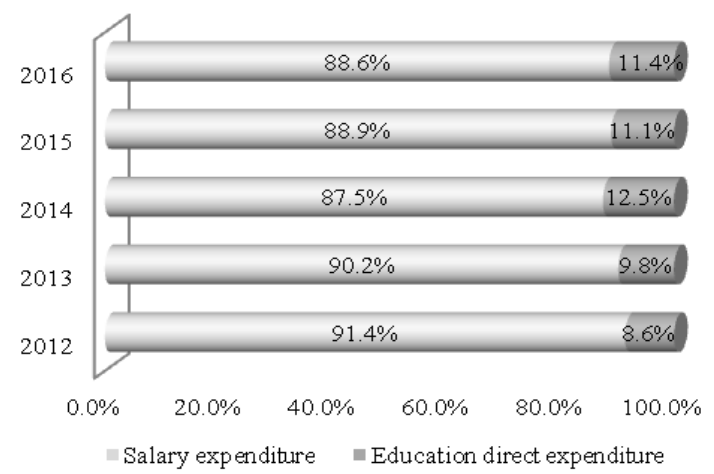

Source: calculation from education office annual budget documents 2012-2016 Figure 3. Components of education expenditure 2012-2016 
The high proportion of salary spending may appear in all district governments in Indonesia, given that teachers comprise the largest number of government officials and most of them have received remuneration (Sujarwoto \& Tampubolon, 2015; Chang, et al, 2014). This means that routine spending in each local government dwarf the spending assigned to project or program implementations.

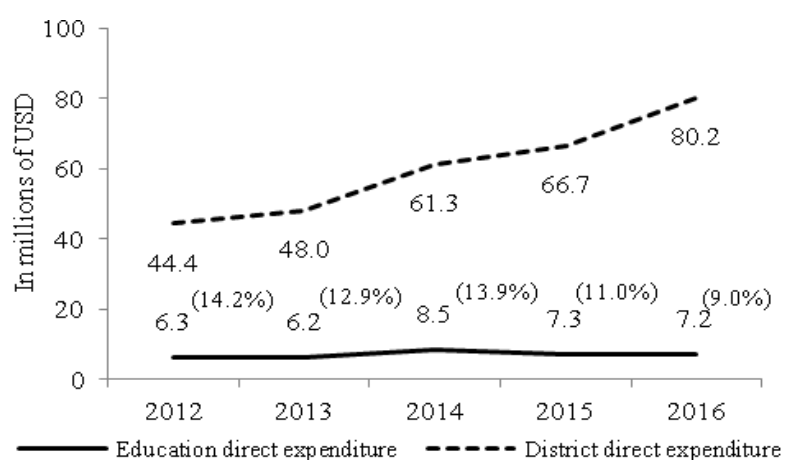

Source: calculation from education office and district annual budget documents (2012-2016)

Figure 4. Proportions of education direct expenditures to district direct expenditure

Second, we found that district government had only considered education as an obligation but not a priority. It could be seen in the proportions of education direct expenditure and district direct expenditure as presented in Figure 4, which illustrates the decreased trend of education direct expenditure between 2012 and 2016. When education is not a priority for district government, it is reflected in its budget allocation for development or in the direct expenditure. Although Sleman enjoys relatively high ownsource revenues for about $26.11 \%$ of total district revenues in 2016, an informant who works at Sleman's local finance office explained that: "The regulation to allocate $20 \%$ of annual budget to the education sector has been fulfilled by the local government. The problem, then, is when local government has to match the allocation of its budgets, not only to central government regulations, but also to the priorities of local leader". The decreased trend of education direct expenditure seemed to be related with the priorities of local leader. It might be hard for the district officials to raise the education budget if the local leader had other priorities.

Although this qualitative finding cannot be generalized for all local governments in Indonesia, it can be one of evidence of the contradictory findings in the implementation of decentralized policy. Third, although it is said that decentralized policy gives more authorities to the local government in managing its expenditures and programs, the central government still requires many mandatory programs to be implemented by local government. As the result, the remaining budget for local initiatives is tightened accordingly. As stated by an informant who works in the Sleman local education agency: "Authority delegation is a mandate based on law. It means that we are still under regulation. [...] We have a special project to keep students from poor families in school by giving financial assistance at the senior high school level. We have not reached yet the lower levels of education because of the minimal budget allocation". This dependency of program implementation mandated by central government seems to be a signal of transfer routine tasks rather than authorities in Indonesia's decentralization of basic education. It is principally because of lack of allocative efficiency that local autonomy has been ineffective in the program implementations. Fiscal autonomy works only if local government has budgets for implementing programs to improve educational accessibility and quality. Local officials must also create proper policies and execute projects that reflect citizens' needs, particularly those of targeted groups such as students from poor families. However, the routine tasks given to district government have minimized the efforts to implement programs needed by the students.

The adequacy of budgets, facilities, and adequate numbers of schools and teachers is expected to decrease school dropouts. However, it would have no meaning if children and parents face financial difficulty. One strategic policy that does effectively reduce school dropout is providing financial assistance for students from poor families. We found such financial assistance for households to be absence at elementary and junior high school levels. Scholarship at least reduces financial burden on parents for school costs. Even though school tuition is said to be free in public schools and be reduced in private schools through School Operational Grants program, but based on interviews with the children and parents in this survey the cases were different. There were other additional fees burdening the parents, such as for additional lesson, uniforms, practice books, extracurricular activities, school trip, and voluntary donation with designed minimum amount for school maintenance. Based on focus group discussion with teachers and principals, school grants, which are calculated based on number of students, given by central and local governments were not enough to cover all of school's needs.

\section{DISCUSSION AND CONCLUSION}

\section{A. Discussion}

By employing a case study in Sleman District, this study explores reasons for dropping out of school by some children at elementary school, transition, and junior high school levels in Sleman district government. It also examines the relationship between decentralized policy in term of fiscal autonomy and school dropout in Indonesia's basic education. We found that before they dropped out, children had experienced several disadvantages triggered by household socioeconomic problems, poor community condition and engagement, which led to poor academic performance, bad social relationship at school, economic-related issue, negative peer group influence. In elementary school level, social relationship at school was the most common reason for dropping out school. Younger children were likely more prone for leaving school if they experienced bad relationships with teachers or friends that made them being traumatized or marginalized. While poor academic performance caused bad relationship with teacher as the teacher sometimes scolded or underestimated the children in 
front of classmates. In sum, children were being embarrassed or traumatized, and decided not going to school. Improving teacher quality particularly pedagogic competency, then, is crucial.

In transition level, the likelihood of children for dropping out of school was mostly related with economical problem since their parents, father in particular, did not support them. Poverty appears to influence the demand for schooling, not only since it affects the inability of households to pay school fees and other costs associated with education, but also because it is associated with a high opportunity cost of schooling for children. This finding highlights prior studies on school dropout in China's rural areas which found the youth labor market condition and the poor family socioeconomic status as the determinant factors of school dropout behavior (Liu, 2004). In junior high school level, the likelihood to drop out of school was typically because of peer group influence. If children have frustration self-esteem or low self-determination, they are more likely to get influence from others. This peer group movement was sometimes not intentionally behaving badly, but since they felt classes were not interesting, they started to skipped class and even missed too many days. These kinds of behavior were also found in developed country such as United States that led children to have poor academic performance because of lack of attention from parents and teachers (Rumberger, 2011). It might lead to another problem such as repetition. When children held back for more than one grades, it will make them older than their classmates, and then drop out because of ashamed.

This study also came to other conclusions that showed the risk of decentralized policy in term of fiscal autonomy on dropping out of school at basic education level. It reflected an inefficiency and incapacity of public education service deliveries in district government. It means that the authorities in managing district revenues to be spent in education sector and program implementations were not based on students' needs but on central government's mandate. It signals that instead of transferring authorities to district government, decentralized policy in Indonesia's basic education only transfers high routine tasks from central government. The qualitative findings explain that district governments did not only financially depend on central government, but also in program implementations. There were many policies and mandatory programs given by central government, such as teacher remuneration, school operational grants, and administrative tasks. Therefore, the majority of budget allocations in district government were dominated by central government programs rather than to be fitted with local needs.

The inefficiency in district budgeting left few spaces for district government to make initiative programs in improving education quality (Sujarwoto, 2012; Sujarwoto and Tampubolon, 2015, 2016). It gives the impression that the performances of teachers and local officials were not satisfying the users or the local people even with their increased salary. Some parents also mentioned their disappointment to the teachers. They said that instead of encouraging their children, the teachers marginalized their children who had poor academic performance or behaved badly at school. It might be the reason for the ineffectiveness of teacher reform in Indonesia as found by Chang, et al. (2014). This research highlights findings of Behrman, Deolalikar, and Soon (2002) whose findings reported that the increased bill for teachers' salaries and incentives contributed to the poor quality of education service and impacted on poor educational outcome achievement in Philippines' junior secondary education.

The qualitative findings also confirmed that when district government had more own-sources revenue and increased total revenue, the allocation for education expenditure had steeply down. Although the local government had high revenue but it does not guarantee that local elite preference will favor local people preference. It seemed that local governments with higher revenues generated locally are more likely to disburse away from improvement in delivering public education services for the interest of the local ruling party leaders as to be found in Cambodia and Pakistan (Eng, 2016). Their finding suggested that having higher degree of fiscal capacity does not necessarily reflect better performance in providing public goods and services since the local officials had only followed and provided local leader's priorities. This finding confirms the argument of Bardhan (2002) who explains the tendency for local government to over-provide the service to local elites at the expense of the non-elite leading to higher economic inequality within communities. Instead of providing efficient public goods and services, local officials and local elites more concern about their own private interests, as they are not pure guardian of public interest (Oates, 2005).

Supply-side factor may work by giving scholarship for poor households as it may reduce financial burdens to parents. Prior study had reported the effectiveness of scholarships in reducing junior high school dropouts in a time of economic crisis in Indonesia (Cameron, 2009), however, due to lack of budget allocation on education sector there was no scholarship initiated by the district government. Improving teacher quality particularly pedagogic competency is also required as the school dropouts mentioned about problems with teachers as one of reasons for dropping out of school. It confirms Chang et al. (2014) findings that showed ineffectiveness of teacher reform in Indonesia in improving student-learning achievement. The mechanism of school operational grants program should also be improved regarding the regulation, which should be assessed not only based on number of students but also the number of poor students, so that poor students will get more financial provisions.

\section{B. Conclusion}

Dropping out of school is not only an individual issue resulted from household socioeconomic factors but also a social issue caused by enabled social policy. Government responsibility and responsiveness to local needs, especially targeting poor households, are essential. Our findings also suggest that, in order to reduce school dropout effectively, local governments must improve their efficiency in allocating 
educational expenditures through implementing strategic policies that directly purposed to help students from dropping out, such as giving scholarship for poor students, improving teacher competency through training and workshop, improving school operational grants calculation for poor students, and having early drop-out detection program.

\section{ACKNOWLEDGMENT}

We are grateful to the anonymous reviewers for careful rounds of review, which have greatly improved the paper. They are naturally exempt from any remaining mistakes.

\section{REFERENCES}

Bardhan, P. (2002). Decentralization of governance and development. Journal of Economic Perspective , 16(4), 185-205.

Behrman, J. R., Deolalikar, A. B., \& Soon, L.-Y. (2002). Promoting effective school trhough education decentralization in Bangladesh, Indonesia, and Phillippines. Manila: Asian Development Bank.

Cameron, L. (2009). Can a public scholarship program successfully reduce school drop-outs in a time of economic crisis? Evidence from Indonesia. Economic of Education Review, 28, 308-317.

Chang, M.C., et al. (2014). Teacher reform in Indonesia: The role of politics and evidence in policy making. Washington D.C.: The World Bank.

Eng, N. (2016). Decentralization in Cambodia: New wine in old bottles. Public Administration and Development. Retrieved from wileyonlinelibrary.com, DOI: 10.1002/pad.1765.

Liu, F. (2004). Basic education in China's rural areas: A legal obligation or an individual choice? International Journal of Educational Development, $24,5-21$.

Ministry of Education and Culture. (2015). Statistics of education and culture 2014/2015 [ Ikhtisar data pendidikan dan kebudayaan tahun 2014/2015]. Jakarta: Indonesia's Ministry of Education and Culture.

Ministry of Finance. (2016). Education expenditures [Anggaran pendidikan]. Cited on April 6, 2016, from http://www.anggaran. depkeu.go.id/dja/athumbs/apbn/ PENDIDIKAN1.pdf

National Statistics Agency of Sleman (2016). GINI Index in Sleman 2015 [Indeks GINI Kabupaten Sleman 2015]. Sleman: BPS-Sleman

Oates, W. (2005). Toward a second generation theory of fiscal federalism. International Tax and Public Finance, 12, 349-373.

Rumberger, R.W. (2011). Dropping out: Why students drop out of high school and what can be done about it. Massachusetts: Harvard University Press.

Sujarwoto \& Tampubolon, G. (2016). Spatial inequality and internet divide in Indonesia. Telecommunication Policy, 40.

Sujarwoto \& Tampubolon, G. (2015). Decentralisation and citizen happiness: A multilevel analysis of self-rated happiness in Indonesia. Journal of Happiness Studies, 16(2), 455-475.

Sujarwoto. (2012). Political decentralization and local public service performance in Indonesia. Journal of Public Administration and Governance, 2(3), 55-84. 